\title{
PENINGKATAN KOMPETENSI MAHASISWA DALAM PENYUSUNAN PROGRAM PENGAJARAN INDIVIDUAL SISWA BERKEBUTUHAN KHUSUS DI KELAS INKLUSIF
}

\author{
Ni'matuzahroh ${ }^{1}$ (D), \\ ${ }^{1}$ Fakultas Psikologi, Universitas Muhammadiyah Malang, Malang, Indonesia
}

\begin{abstract}
This research aimed to improve students' ability in developing Individual Teaching Program (PPI) Module for Children with Special Need. This study used quasi experimental with between-group design. Seventh semester of Psychology students who was taking a Psychology for Children with Special Need course were the subject of the research. Data collection was obtained through observation, interview, Focus Group Discussion, and documentation. The data analysis was descriptive-quantitative. The analysis result was used to interpret the research findings. The findings showed that most of the subjects got more understanding after treatment. The study implies that in the future research, it is necessary to conduct sustainable guided program, intensive time table, and implementation of the program so that the subjects experience the real practice.
\end{abstract}

Keywords: Developing Individual Teaching Program, Children with Special Need, Inclusive Class.

\begin{abstract}
ABSTRAK
Penelitian ini bertujuan untuk meningkatkan kemampuan mahasiswa dalam menyusun modul program pengajaran individu (PPI) siswa berkebutuhan khusus di kelas inklusif. Penelitian ini merupakan penelitian quasi eksperimen dengan between-group design. Subjek penelitian adalah mahasiswa semester VI Fakultas Psikologi yang mengikuti mata kuliah psikologi individu berkebutuhan khusus. Metode pengumpulan data menggunakan observasi, wawancara, FGD dan dokumentasi. Analisis data dilakukan secara deskriptif kuantitatif. Hasil observasi, wawancara, FGD dan dokumentasi selanjutnya dianalisis dan digunakan sebagai dasar untuk menginterpretasi hasil penelitian. Hasil penelitian menunjukan Subyek memiliki pemahaman yang baik dalam menangkap dan mempraktekkan materi pelatihan, dimana dari kedua kelas, subyek yang memiliki pemahaman yang baik lebih banyak dari pada subyek yang kurang memahami. Hal ini menunjukkan bahwa pelatihan ini efektif dalam meningkatkan pengetahuan subyek tentang penyusunan program pembelajaran individual. Implikasi dari penelitian ini adalah perlunya program pendampingan yang berkelanjutan dan waktu yang lebih intensif serta penerapan program agar subyek benar-benar memahami kelemahan dan kelebihan dari program yang telah dibuatnya.
\end{abstract}

Kata kunci: Penyusunan Program Pembelajaran Individual, Siswa Berkebutuhan Khusus, Kelas Inklusif. 


\section{PENDAHULUAN}

Pendidikan inklusi merupakan pendidikan yang menyatukan semua anak dalam satu proses pembelajaran tanpa memandang perbedaan latar belakang siswa dalam sebuah layanan pendidikan yang layak dan sesuai dengan kebutuhan individu siswa. Dalam kelas inklusi, siswa tidak dibedakan berdasarkan tingkat kecerdasan atau keterbatasan fisik atau mentalnya melainkan semua anak diperlakukan sama. Prinsip dasar dalam pendidikan inklusi adalah selama memungkinkan semua anak-anak dapat belajar bersama-sama.

Dalam perjalanan penerapan inklusi, terdapat berbagai permasalahan yang ada diantaranya adalah kesiapan sekolah penyelenggara yang minim meliputi kurangnya pengajar yang kompeten, kurikulum yang berdiferensiasi sesuai dengan kapasitas siswa ABK, kesadaran dan pemahaman teman sebaya dan orang tuanya tentang kehadiran siswa berkebutuhan khusus di sekolah. Hasil penelitian Ni'matuzahroh (2016) menunjukkan bahwa meskipun para guru inklusi memiliki sikap yang mendukung penyelenggaraan kelas inklusi namun mereka merasa bahwa sekolah belum siap dalam menyelenggarakan kelas inklusi karena belum memiliki pengetahuan dan sarana yang memadai tentang penyelenggaraan inklusi. Penelitian tersebut juga menunjukkan bahwa guru perlu diberikan wawasan dan pelatihan tentang pengelolaan kelas inklusi yang diarahkan pada 3 hal yaitu pengetahuan tentang karakteristik siswa berkebutuhan khusus dan identifikasinya, kegiatan penyusunan program pembelajaran individual untuk siswa $\mathrm{ABK}$ serta pemberian keterampilan tentang pengelolan stress.

Workshop pembentukan jaringan kerja penanganan dan persiapan siswa berkebutuhan khusus menuju pendidikan formal menunjukkan berbagai permasalahan dalam pendidikan inklusif diantaranya terbatasnya pengetahuan guru tentang pendidikan inklusi, pemahaman yang salah dari orangtua tentang pendidikan inklusi, minimnya sarana dan prasarana pendukung pembelajaran, serta kurang terstandarnya alat tes yang mampu mendeteksi siswa secara cepat dan akurat.

Penelitian tersebut menghasilkan permasalahan yang sama dengan permasalahan yang dihadapi Pemkot Surabaya terkait dengan pendidikan inklusif yaitu sama-sama memiliki permasalahan terkait minimnya dan belum meratanya guru inklusif yang memiliki latar belakang pendidikan luar biasa di kelas inklusi disamping masalah lain seperti pemahaman masyarakat yang belum sepenuhnya lengkap tentang sekolah inklusif, masih banyak orangtua murid yang memiliki sekolah inklusif yang jauh 
dari rumah, dan belum tersedianya ruang khusus untuk terapis bagi anak berkebutuhan khusus di sekolah inklusif (Dinas Pendidikan Pemkot Surabaya, 2014).

Hasil wawancara peneliti dengan guruguru inklusi di Kota Malang dan Batu diketahui bahwa mereka sangat membutuhkan pendampingan terutama dalam hal penanganan siswa berkebutuhan khusus di kelas inklusi, terutama karena mereka kurang memahami karakteristik siswa berkebutuhan khusus serta minimnya pengetahuan tentang penanganan siswa berkebutuhan khusus di kelas, sehingga mereka menyikapi siswa sama dengan siswa reguler lainnya, namun dengan perhatian yang khusus.

Dari berbagai permasalahan tersebut tampak bahwa sekolah inklusi serta gurugurunya sangat membutuhkan pendampingan bagi terlaksananya pendidikan inklusif yang ideal, terutama untuk dapat menyusun program pengajaran individual. Salah satu cara yang dapat dilakukan adalah melatih mahasiswa psikologi yang dapat diterjunkan sebagai fasilitator maupun trainer untuk dapat melatih guru-guru. Mahasiswa psikologi semester VI merupakan mahasiswa yang sedang menempuh mata kuliah aplikasi dalam pendidikan. Melalui mata kuliah ini, mahasiswa diharapkan dapat terjun ke masyarakat dan sekolah untuk melakukan assesmen dan intervensi terhadap permasalahan-permasalahan yang dihadapi disekolah, salah satunya permasalahan di kelas inklusif.

Penelitian ini bertujuan untuk melihat efektifitas pelatihan penyusunan program pembelajaran individual pada mahasiswa semester VI yang menempuh mata kuliah psikologi individu berkebutuhan khusus, dengan indikator pemahaman mahasiswa terhadap manfaat dari penyusunan program pembelajaran.

\section{A. Program Pengajaran Individual Bagi Siswa ABK}

Hallahan, Kauffman dan Pullen (2009) menjelaskan bahwa desain pembelajaran dalam pendidikan inklusif harus didesain khusus agar pembelajaran bisa optimal terutama materi pembelajaran, teknik pembelajaran, kurikulum, sistem evaluasi dan fasilitas penunjang yang memadai seperti transportasi khusus, asesmen psikologi, terapi, pengobatan khusus dan konseling yang dibutuhkan agar pembelajaran berjalan efektif karena tujuan utama dari pendidikan inklusif ini adalah menemukan dan mengembangkan kemampuan khusus siswa. Hal senada juga dikemukakan oleh Thomas dan Hanlon (2007) menegaskan bahwa pendidikan inklusif tidak hanya sebatas melakukan 
mencampur siswa $\mathrm{ABK}$ dengan siswa non $\mathrm{ABK}$ melainkan juga menyiapkan prosedur dan sistem pembelajaran khusus untuk mereka. Berdasarkan hasil penelitian Zigmond (dalam Hallahan, Kauffman \& Pullen, 2009) penyelenggaraan inklusif membutuhkan persiapan sejumlah prioritas dan menyeleksi secara hati-hati apa yang dibutuhkan untuk diajarkan, lebih jelasnya dipertegas dengan penekanan pada istilah mengajar sesuatu yang khusus dan mengajarkannya dengan cara yang khusus pula. Berdasarkan hasil penelitian sebelumnya yang dilakukan oleh Gersten, Shiller dan Vaughn (dalam Hallahan, Kauffman \& Pullen, 2009) beberapa hal yang digunakan dalam kelas-kelas inklusif saat ini adalah pembelajaran berbasis komunitas (communitybased instruction), pembelajaran langsung, selfmonitoring, asesmen perilaku, adaptasi sistem pembelajaran dan fasilitas pendidikan.

Siswa berkebutuhan khusus membutuhkan kurikulum tersendiri di kelas inklusi sehingga perlunya memilih kegiatan belajar yang paling efektif dan efisien dalam memberikan pengalaman belajar pada mereka. Sekolah inklusi dan guru harus membuat tujuan instruksional yang mengacu kepada kekhususan mereka. Program pengajaran individual menurut Depdikbud (dalam Mangunsong, 2009) merupakan kegiatan yang dipilih guru dalam proses belajar mengajar, yang dapat memberikan kemudahan atau fasilitas kepada siswa menuju tercapainya tujuan instruksional tertentu yang telah ditetapkan. Tujuan dari PPI adalah mendeskripsikan serangkaian strategi yang diarahkan untuk kebutuhan pengajaran khusus bagi siswa ABK (Education, diakses 2014). Program pengajaran individu merupakan menuliskan rencana pembelajaran untuk siswa yang didalamnya dideskripsikan tentang pengajaran khusus dan dihubungkan dengan layanan yang akan diterima siswa ABK (Vermont Family Network, 2014). Penyusunan PPI dilakukan secara bersama-sama oleh orangtua, guru kelas, terapis. Dalam penyusunan instruksional pembelajaran ditentukan atas tiga pertimbangan yaitu tujuan instruksional dari pembelajaran, bentuk dan isi dari materi pelajaran dan karakteristik serta kemampuan siswa (Ormrod, dalam Mangunsong 2014).

\section{B. Prinsip-Prinsip dalam pemilihan Strategi Pengajaran Bagi Berkebutuhan Khusus}

Dalam penyusunan strategi pengajaran beberapa hal yang diperhatikan adalah: 1. Tipe kecacatan dan tingkat keparahan siswa, 2. Tingkatan usia siswa, perkembangan fisik maupun psikis, perlunya memperhatikan tingkatan usia adalah untuk menentukan metode pengajaran. Adapun Langkah-langkah dalam 
pemilihan strategi pengajaran individual adalah identifikasi atribut-atribut, menentukan tujuantujuan pengajaran, pemilihan strategi, pemilihan materi, uji strategi dan materi, serta evaluasi performansi (Mangunsong, 2009). Tujuan dari Penyusunan program pembelajaran individual adalah agar tiap siswa $\mathrm{ABK}$ mendapat perlakuan dalam proses pembelajaran yang sesuai dengan kebutuhannya.

Kompleksitas program pembelajaran individual sangat tergantung pada kebutuhan individu. Semakin kompleks permasalahannya, maka semakin detil program pembelajaran individual yang dibuat untuk individu tersebut. Sebuah program pembelajaran individual perlu mencakup tujuan pembelajaran individual, makna penting mencapai tujuan tersebut, layanan tambahan yang diperlukan serta bagaimana layanan tersebut diberikan. Sehingga diharapkan program pembelajaran individual dapat menjadi petunjuk bagi guru untuk memantau pertumbuhan dan kemajuan peserta didik yang berkebutuhan khusus.

$$
\text { Dalam pembuatan program }
$$
pembelajaran individual, ada tiga tahapan penting yang harus selalu dilalui, yaitu perencanaan (planning), pelaksanaan (implementing), dan evaluasi (evaluating). Ketiga tahap tersebut terdiri atas tujuh komponen aktivitas yang perlu dilakukan, yaitu asesmen, kolaborasi, penulisan, pengenalan, pemantauan (monitoring), peninjauan (reviewing), dan pelaporan (Ministry of Education Province of British Columbia, 2009).

\section{Tahap Perencanaan}

Asesmen dan kolaborasi perlu dilakukan sebagai bagian dari perencanaan sebelum memulai tahap penulisan program pembelajaran individual. Pertanyaannya, mengapa asesmen untuk siswa berkebutuhan khusus menjadi sesuatu yang penting? Ada beberapa tujuan yang sekaligus dapat dicapai dari asesmen, yaitu: Identifikasi atau screening awal, Penentuan dan evaluasi dari proses pembelajaran, Penetapan dari tingkat performansi dan kebutuhan pendidikan, keputusan tentang kelayakan, pengembangan program pendidikan individual dan keputusan tentang penempatan program. (Taylor, 2009).

Secara umum, proses asesmen terdiri atas 4 jenis kegiatan, yaitu Reviewing, Interviewing, Observing, dan Testing. Sebelum mengaplikasikan sebuah rancangan pembelajaran kepada siswa berkebutuhan khusus, tim perancang program pembelajaran individual (yang biasanya terdiri atas guru, manager kasus, konselor sekolah, ahli komunitas, orangtua, dan terapis) perlu mengetahui kemampuan dan kesiapan peserta 
didik. Asesmen kemampuan (abilities) meliputi asesmen inteligensi, perilaku adaptif dan Asesmen status emosi dan perilaku Asesmen bahasa lisan serta asesmen prestasi (achievement) yang meliputi: Prestasi umum dan kemampuan membaca. Inventori dan tes khusus dilakukan untuk mengetahui kemampuan membaca siswa berkebutuhan khusus, kemampuan matematika, kemampuan mengeluarkan ekspresi tertulis (written expression). Selain melakukan asesmen bahasa lisan sebagai tolok ukur kemampuan berbahasa siswa berkebutuhan khusus, perancang PPI juga perlu melakukan asesmen terkait kemampuan mengeluarkan ekspresi tertulis pada siswa berkebutuhan khusus, karena ada siswa yang memiliki kemampuan berbahasa lisan yang buruk tetapi sangat lihai mengolah kata dalam bahasa tertulis, misalnya saja Temple Grandin, seorang profesor ilmu peternakan yang merupakan penderita asperger. Grandin memiliki kesulitan berbahasa lisan, tetapi mampu mengekspresikan pikiran-pikirannya melalui tulisan sampai akhirnya dibukukan.

Dalam kasus siswa berkebutuhan khusus, semakin dini gangguan diidentifikasi, maka akan semakin cepat penanganan yang bisa dilakukan untuk mengatasinya. Hal-hal yang ada dalam penulisan PPI adalah a. Tujuan (goals and objectives) yang ingin dicapai dari proses pendidikan dalam rentang waktu tertentu. Penetapan tujuan ini harus mengacu pada konsep SMART (Specific, Measurable, Achievable and action-oriented, Realistic, dan Time-Limited).

b. Strategi yang relevan untuk mencapai tujuan.

c. Metode asesmen yang dapat digunakan untuk memantau perkembangan peserta didik dan mengevaluasi PPI yang telah dibuat.

2. Tahap Pelaksanaan

Setelah PPI selesai dibuat, maka PPI dapat diperkenalkan kepada peserta didik untuk kemudian diaplikasikan. Tujuan perkenalan ini adalah agar peserta didik mengetahui tujuan yang ingin dicapai dalam pembelajarannya dan memahami peran yang harus dia lakukan agar tujuan tersebut dapat dicapai. Guru sebagai penanggungjawab pelaksanaan PPI juga perlu memastikan kepada siswa bahwa semua kebutuhan pendidikannya akan didukung oleh pihak-pihak lain sesuai kebutuhannya. Pada fase ini, komunikasi yang berkualitas antar pemangku kepentingan yang telah terjalin dari proses awal harus tetap dipelihara, sehingga fungsi kontrol dan pemantauan perkembangan siswa tetap terjaga.

Pemantauan (monitoring) merupakan suatu proses di mana para pendidik menilai 
respon siswa terhadap strategi yang diterapkan apakah dapat memenuhi tujuan yang dicanangkan. Proses pemantauan dilakukan oleh seluruh anggota pembuat PPI dengan guru sebagai penanggungjawab utamanya. Caranya adalah dengan menggunakan serangkaian metode asesmen baik formal maupun informal, seperti misalnya dengan menggunakan behavioral checklist untuk melakukan observasi. Proses pemantauan ini nantinya akan menghasilkan feedback atau umpan balik agar dapat dilakukan berbagai penyesuaian jika data menunjukkan bahwa strategi yang diaplikasikan kurang cocok bagi siswa atau tujuan yang dicanangkan kurang realistis. Masukan dapat diberikan oleh siapapun anggota yang terlibat dalam pembuatan PPI, termasuk orangtua dan siswa sendiri. Akan tetapi sebelum memutuskan bahwa suatu strategi tidak efektif, maka perlu dipastikan kembali kesiapan siswa untuk mencapai tujuan yang telah ditetapkan, faktor yang menghambat kemajuan siswa tetapi belum terpantau, perubahan yang terjadi pada siswa di luar sekolah, dan situasi yang dibuat terlalu menantang untuk siswa.

\section{Tahap Evaluasi}

Pada tahap ini, ada dua kegiatan pokok yang perlu dilakukan, yaitu peninjauan (reviewing) dan pelaporan. Peninjauan perlu dilakukan untuk menentukan kelayakan dan keefektifan sebuah PPI, melihat kemajuan siswa, dan mengidentifikasi strategi yang efektif pada masa persiapan transisi. Idealnya, tiap PPI setidaknya ditinjau setahun sekali. Tinjauan terhadap PPI ini menjadi dasar untuk membuat PPI pada tahun berikutnya, sehingga jika seorang siswa naik kelas, guru di tingkat berikutnya tidak perlu membuat PPI dari awal, hanya perlu melanjutkan saja berdasarkan evaluasi terhadap kemajuan yang dibuat oleh siswa. Sehingga ada kontinyuitas dalam proses pembelajaran siswa berkebutuhan khusus.

Laporan kemajuan menggambarkan proses dan kemajuan yang dibuat oleh siswa selama proses pembelajaran yang direncanakan dalam PPI diimplementasikan. Sebisa mungkin penulisan laporan bebas dari jargon sehingga bisa diakses oleh semua anggota tim PPI, bahkan yang paling awam sekalipun.

\section{Pengertian dan Faktor Penyebab Siswa Berkebutuhan Khusus}

Suran dan Rizzo (dalam mangunsong, 2009) menjelaskan siswa Berkebutuhan khusus adalah anak yang secara signifikan berbeda dalam beberapa dimensi yang penting dari fungsi kemanusiaannya. Mereka secara fisik, psikologis, kognitif atau sosial terhambat dalam mencapai tujuan/kebutuhan dan potensinya secara maksimal. Hallahan dan Kauffman 
(2007) mendefinisikan siswa berkebutuhan khusus sebagai mereka yang memerlukan pendidikan khusus dan layanan terkait. Gearheart (dalam Mangunsong, 2009) mengatakan bahwa seorang anak dianggap berkelainan bila memerlukan persyaratan pendidikan yang berbeda dari rata-rata anak normal. Anak-anak ini membutuhkan program, pelayanan dan materi khusus untuk dapat belajar secara efektif memerlukkan. Mangunsong (2009) menyatakan bahwa anak berkebutuhan khusus adalah anak yang menyimpang dari ratarata anak normal dalam hal: ciri-ciri mental, kemampuan-kemampuan sensorik, fisik dan neuromaskular, perilaku sosial dan emosional, kemampuan berkomunikasi, maupun kombinasi dua atau lebih dari hal-hal diatas, sejauh mereka memerlukan modifikasi dari tugas-tugas sekolah, metode belajar atau layanan terkait, yang ditujukan untuk mengembangkan potensi atau kapasitas secara maksimal.

Suzan dan Rizzo (dalam Mangunsong, 2009) menjelaskan tentang anak-anak yang termasuk berkebutuhan khusus adalah mereka yang tuli, buta, mempunyai gangguan bicara, cacat tubuh, retardasi mental, gangguang emosional, juga anak-anak yang berbakat luar biasa yang membutuhkan layanan khusus. Gangguan tersebut mempengaruhi perkembangan anak seperti hasil penelitian yang dilakukan oleh Fletcher, J.M, et.al (1994) menunjukkan bahwa kesulitan membaca membuat anak memiliki gangguan kesadaran fonology (Phonologycal awareness). Hasil penelitian Friedman, Harvey, Youngwirth dan Goldstein (2007) membuktikan bahwa ada hubungan yang signifikan antara symptom inattention, hiperaktif dan agresi anak usia 3 tahun dengan kemampuan kognitif, motorik dan akademik awal mereka. Dari data orangtua diketahui bahwa anak-anak dengan dengan ADHD diiringi agresi atau tidak, sebagian besar mengalami masalah akademik dan masalah kognitif, sementara data dari guru diketahui bahwa symptom inattention, hiperaktif dan agresi anak usia 3 tahun tidak hanya berhubungan dengan masalah ketrampilan pra akademik melainkan juga berhubungan dengan masalah kemampuan kognitif dan motorik.

Penyebab gangguan memang beragam namun, Hallahan, dkk (2009) dan Freind (2005) mengemukakan faktor yang menyebabkan gangguan ABK secara umum adalah yaitu: Faktor neurologi yaitu adanya disfungsi pada Central Nervous System (CNS) atau sistem syaraf pusat. Freind, (2005) juga menyatakan bahwa ukuran otak anak $A D H D$ terlihat lebih kecil dengan aktifitas metabolik yang lebih sedikit Faktor genetik seperti pada Gangguan $L D$ merupakan gangguan yang sifatnya 
herediter, dimana berdasarkan hasil penelitian diketahui bahwa 35-45\% dari individu yang mengalami $L D$ memiliki orangtua dan saudara yang $L D$ pula. Resiko terkena $L D$ juga pada anak yang memiliki kedua orangtua $L D$, atau pada anak-anak yang memiliki keluarga yang mengalami gangguan bicara dan bahasa, dan ADHD National Institute of Mental Health (dalam Friend, 2005; Rief, 1993) anak-anak yang memiliki orang tua $A D H D$ beresiko mengalami $A D H D 3$ kali lipat dibanding anak lainnya. Faktor Teratogenic yaitu kerusakan perkembangan janin dimana faktor perantara yang dapat menyebabkan cacat atau kerusakan dalam perkembangan janin seperti Fetal Alcohol Syndrome (FAS) yaitu suatu kondisi dimana bayi lahir dengan berat badan kurang, kemunduran intelektual, dan ketidaksempurnaan bentuk fisik yang merupakan penyebab utama dari kesulitan intelektual, Toxin : yaitu keracunan timah yang merupakan faktor yang dapat menyebabkan kesalahan pembentukan (malformation) pada perkembangan fetus pada wanita hamil (Hallahan, 2009) Faktor medis karena kelahiran premature komplikasi pada saat lahir, rendahnya berat badan (Hallahan, 2009), dan kekurangan oksigen pada saat proses kelahiran (Freind, 2005) menempatkan anak dalam resiko disfungsi neurologi dan pediatric AIDS yang menyebabkan kerusakan syaraf.

Menurut Freind (2005) faktor lingkungan berupa pola asuh yang permisif, ibu hamil yang merokok, minum alkohol atau menggunakan obat-obatan. Penelitian Friedman, Youngwirth dan Goldstein (2007) menyimpulkan bahwa masalah kognitif dan masalah pra-akademik pada anak-anak mulai muncul pada awal usia 3 tahun dan menyoroti tentang pentingnya mengevaluasi hubungan antara masalah prilaku lainnya dengan kemampuan anak-anak.

\section{Pengertian Pendidikan Inklusif}

Pendidikan inklusif merupakan sebuah strategi untuk mewujudkan pendidikan universal guna menciptakan sekolah yang responsif terhadap beragam kebutuhan aktual anak dan masyarakat dan mensyaratkan ABK belajar disekolah-sekolah terdekat dikelas biasa bersama anak-anak seusianya (Stubbs, 2002). Anak yang tergolong berkebutuhan khusus antara lain mereka yang memerlukan pendidikan yang berbeda dari rata-rata anak normal dan untuk dapat belajar secara efektif memerlukan program, pelayanan dan materi khusus (Gearheart dalam Mangunsong, 2009; Fletcher, J.M, et.al,1994; Friedma, Harvey, youngwirth dan goldstein, 2007), yang 
disebabkan oleh faktor neurologi (Hallahan, dkk, 2009; Freind,2005), genetik, (Friend, 2005; Rief, 1993), kerusakan perkembangan janin, kelahiran prematur, dan proses kelahiran (Hallahan, 2009; Freind, 2005).

Penelitian longitudinal yang dilakukan oleh Ronka; 1999, Jessor;1998; Rutter \& rutter; 1992 (dalam Visser, Daniels \& Cole, 2001) ada 2 faktor resiko yang membuat anak-anak memiliki pengalaman buruk yang kemudian membutuhkan pendidikan khusus yaitu faktor internal yaitu rendahnya kontrol emosi dalam diri, pengalaman negatif disekolah dan rendahnya harga diri. Sementara faktor eksternalnya adalah rendahnya sosial ekonomi orangtua, rendahnya pendidikan, kekerasan dalam keluarga dan keluarga yang alkoholisme. Dalam peneltian ini ditemukan bahwa anakanak yang memiliki pengalaman buruk di masa kecilnya akan mengalami pengalaman buruk pula manakala mereka dewasa. Hasil penelitian Biederman, Faraone, dan Monuteaux (2002) kelas sosial yang rendah, ibu yang mengalami psikopatologi, dan konflik keluarga secara signifikan dihubungkan dengan psikopatologi dan kerusakan/pelemahan fungsional didalam otak (meningkatkan resiko $A D H D$ ), ADHD juga berhubungan dengan orangtua dan ibu yang selama kehamilan merokok. Menurut Freind, (2005) faktor lingkungan berupa pola asuh yang permisif, ibu hamil yang merokok, minum alkohol atau menggunakan obat-obatan. Penelitian Friedman, Youngwirth dan Goldstein (2007) menyimpulkan bahwa masalah kognitif dan masalah pra-akademik pada anak-anak mulai muncul pada awal usia 3 tahun dan menyoroti tentang pentingnya mengevaluasi hubungan antara masalah prilaku lainnya dengan kemampuan anak-anak.

Tujuan utama dari pendidikan inklusif adalah untuk mendidik anak berkebutuhan khusus dikelas reguler bersama-sama dengan anak yang non-cacat dengan dukungan yang sesuai dengan kebutuhannya disekolah yang terdekat dengan tempat tinggalnya dan tanpa diskriminatif (Stubbs, 2002 ; Direktorat pembinaan SLB, 2007; Direktorat pembinaan SLB, 2007).

Stubbs (2002) menegaskan bahwa, meski pendidikan inklusif mengarah pada integrasi dan penempatan kelas reguler namun dengan filosofi yang berbeda. Konsep pendidikan inklusif bergagasan bahwa sekolah harus menyediakan pendidikan yang dibutuhkan anak dalam komunitas tersebut apapun tingkat dan kemampuan mereka. Dalam konteks pendidikan inklusif semua anak dengan berbagai latar belakang sosial ekonomi, sosial dan kultural dan emosional baik fisik dan nonfisik dapat belajar bersama-sama sesuai 
kebutuhan mereka sesuai dengan kebutuhan mereka masing-masing (Direktorat pembinaan SLB, 2007).

\section{E. Pendidikan Inklusif di Indonesia}

Pendidikan inklusif lahir diawali adanya kesadaran masyarakat terhadap hak azazi manusia dan kesadaran terhadap perbedaan yang bukan menjadi sesuatu yang menyimpang melainkan sebagai sesuatu yang patut disyukuri untuk kemudian menjadi saling melengkapi. Termasuk dalam hal pendidikan, setiap warga negara berhak mendapatkan kesempatan yang sama yang tertuang dalam UUD 45 pasal 28C ayat 1 dan pasal 9 ayat 1 bahwa setiap anak berhak memperoleh pendidikan dan pengajaran dalam rangka pengembangan kepribadian dan kecerdasan sesuai minat bakatnya yang berlaku pula untuk anak berkebutuhan khusus. Dari kesadaran tersebut kemudian muncullah pendidikan inklusif yang dijadikan sebuah strategi untuk mewujudkan pendidikan universal guna menciptakan sekolah yang responsif terhadap beragam kebutuhan aktual anak dan masyarakat (Stubbs, 2002). Sejak tahun 2000 pemerintah mengembangkan pendidikan inklusif ini kemudian dilanjutkan dengan simposium internsional di Bukit tinggi tahun 2005 yang menghasilkan penekanan pada perlunya terus dikembangkan program pendidikan inklusif (Mangunsong, 2009).
Kemudian dikeluarkan surat edaran Dirjen Dikdasmen Depdiknas No.380/C.C6/MN/2003 tanggal 20 Januari 2003, perihal pendidikan inklusif, maka pendidikan inklusif ini mulai diselenggarakan dan dikembangkan di setiap kabupaten/Kota yang terdiri dari SD, SMP, SMA dan SMK (Ditjen Dikdasmen, 2007).

Namun persoalannya pendidikan inklusif belum terlaksana sebagaimana yang diidealkan karena berbagai keterbatasan yang ada didalam pelaksanaanya meski sejak tahun 2004 telah dilakukan berbagai pelatihan bagi masing-masing penyelenggara pendidikan inklusif, namun pemimpin dan perwakilan guru yang dilatih belum dapat menyebarkan infomasi maupun pengetahuan yang diperoleh (Mangunsong, 2009). Dari hasil-hasil penelitian diketahui berbagai permasalahan dalam penyelenggaraan sekolah seperti kesiapan orangtua dan siswa non abk menerima keberadaan siswa, belum siapnya tenaga pendidikan inklusif, fasilitas yang belum mendukung, dll, sehingga pembelajaran di kelas inklusif belum optimal. Bahkan ABK disekolahsekolah inklusif masih menerima model pengajaran yang beragam dan belum sepenuh sesuai dengan prinsip pendidikan inklusif, dikelas yang lebih lanjut seperti di SMP dan SMA pendekatan pembelajarannya masih berupa pendidikan terpadu atau terintegrasi 
tanpa adanya modifikasi dalam pengajaran yang sesuai (Mangunsong, 2009). Dari uraian tersebut tampak jelas bahwa pendidikan inklusif masih memerlukan pembenahan dalam berbagai bidang.

\section{METODE PENELITIAN}

\section{Rancangan Penelitian}

Penelitian ini merupakan penelitian quasi ekperimen karena tidak dilakukan prosedur acak sepenuhnya. Penelitian quasi eksperimen ini mengelompokkan subyek ke dalam kelompok eksperimen tidak dilakukan randomisasi tetapi berdasarkan kelompok yang sudah ada (Creswell, 2014; Seniati, 2008; Cristensen, 1988). Rancangan penelitian ini merupakan rancangan penelitian between group desain dimana peneliti mencoba mengetahui peningkatan yang dialami oleh subyek dalam kelompok itu sendiri dari hasil sebelum pretes dan sesudah pretes, kemudian membandingkannya dengan kelompok lain (Cresswell, 2014).

\section{Prosedur Penelitian}

Penelitian ini dilakukan dengan tahapan pemberian materi tentang memahami karakteristik individu berkebutuhan khusus, melakukan asesmen dan menyusun program pengajaran individual.

\section{Subyek Penelitian}

Subyek dalam penelitian ini adalah 80 orang mahasiswa Fakultas Psikologi Universitas Muhammadiyah Malang semester VI yang mengambil mata kuliah psikologi individu berkebutuhan khusus.

\section{Metode Pengumpulan Data}

Pengumpulan data menggunakan berbagai metode yang saling melengkapi, yang meliputi observasi, wawancara, dan FGD serta dokumentasi. Metode observasi dan wawancara digunakan untuk melakukan asesmen terhadap kemampuan mahasiswa, FGD digunakan untuk penyampaian materi sekaligus evaluasi kegiatan pelatihan. Dokumentasi digunakan untuk pengumpulan data-data yang dibutuhkan dalam penelitian.

\section{Jenis Data}

Data yang digunakan dalam penelitian ini adalah data primer dan sekunder. Data primer mencakup data hasil observasi dan wawancara dan instrumen. Sedangkan data sekunder adalah data-data dari dokumen yang dimiliki sekolah terkait pengajaran dan pengelolaan dikelas inklusi.

\section{Metode Analisa Data \\ Analisa data menggunakan analisa deskriptif kuantitatif, dimana data-data yang}


diperoleh dianalisas secara seksama untuk kemudian diambil kesimpulan.

\section{HASIL PENELITIAN}

\section{Deskripsi Subyek Penelitian}

Subyek penelitian ini adalah mahasiswa fakultas psikologi UMM semester VI yang mengambil Mata Kuliah Psikologi Individu Berkebutuhan Khusus. Dengan deskripsi sebagai berikut:

Tabel 1. Deskripsi Partisipan Penelitian

\begin{tabular}{cccc}
\hline Kelas & $\begin{array}{c}\text { Jenis } \\
\text { Kelamin }\end{array}$ & Jumlah & Prosentase \\
\hline \multirow{2}{*}{ A } & Laki-laki & 13 orang & $27 \%$ \\
\cline { 2 - 4 } & Perempuan & 34 orang & $73 \%$ \\
\hline & Total & 47 orang & $100 \%$ \\
\hline \multirow{3}{*}{ B } & Laki-laki & 10 orang & $25 \%$ \\
\cline { 2 - 4 } & Perempuan & 30 orang & $75 \%$ \\
\hline & Total & 40 orang & $100 \%$ \\
\hline
\end{tabular}

\section{Deksripsi Hasil Pelatihan Penyusunan Program Pembelajaran Individual.}

Penelitian ini dilakukan selama 4 bulan dengan memberikan berbagai pengetahuan yang dibutuhkan agar mereka mampu menyusun PPI yang benar. Pada tahap ini subyek diberikan berbagai pengetahuan antara lain pengetahuan tentang:

\section{a. Pelatihan memahami karakteristik siswa berkebutuhan khusus \\ Pada tahap ini subyek diberikan berbagai pengtahuan antara lain pengetahuan}

tentang landasan filosofi tentang siswa berkebutuhan khusus, kemudian mereka di bagi menjadi beberapa kelompok yang ditugaskan untuk membuat makalah tentang siswa berkebutuhan khusus, masing-masing kelompok membahas satu jenis gangguan yaitu autisme, ADHD, Gifted, Retardasi Mental, Kesulitan Belajar, korban bencana, anak jalanan, siswa dari daerah 3 T. Makalah tersebut harus dipresentasikan di depan kelas, mereka harus membuat mind map untuk dibagikan kepada peserta kelompok lain dan membuat PPT yang menarik. Tugas lainnya pada saat kelompok lain presentasi, setiap orang di minta untuk membuat ringkasan berupa mind map. Sehingga masing-masing orang membuat 8 mind map dengan topik yang berbeda. Tugas ini bertujuan untuk memastikan bahwa setiap subjek memahami semua materi, tidak hanya materi yang mereka bahas dalam kelompok.

b. Aktivitas penelusuran jurnal terkait siswa berkebutuhan khusus

Aktivitas ini bertujuan untuk memberikan pengetahuan subyek tentang isu-isu terkini tentang penanganan siswa IBK di seluruh dunia. Subyek diminta untuk mencari 2 jurnal terbaru kemudian menelaah 2 jurnal 
tersebut. Aktifitas review jurnal ini terbagi dalam 2 tugas :

1. Review jurnal dipresentasikannya pada teman di kelompoknya. Setiap individu diminta untuk menelaah 2 jurnal 3 tahun terakhir mulai tahun 2013 sampai 2016. Kemudian tiap subyek mempresentasikannya di kelompok masing-masing yang terdiri dari 6 orang dan setiap orang membuat ringkasan review jurnal yang dipresentasikan semua anggota kelompok sehingga setiap orang memiliki 12 jurnal. Setelah presentasi di kelompok selesai, kelompok memilih 2 jurnal yang terbaik untuk dipresentasikan dalam forum kelas.

2. Presentasi dalam forum kelas

Dua jurnal pilihan kelompok dipresentasikan didepan kelas dan setiap kelompok wajib membuat ringkasan review jurnal dari kelompok lain. Dalam aktivitas ini terdapat 8 kelompok, sehingga setiap kelompok memiliki 14 resume review jurnal dari kelompok lain. Kegiatan ini bertujuan agar mahasiswa memiliki pengetahuan tentang penanganan $\mathrm{ABK}$ yang terkini dari berbagai jurnal penelitian sehingga mereka mendapat gambaran yang jelas tentang penanganan yang telah ada.

\section{c. Pelatihan tentang teknik asesmen dan identifikasi siswa berkebutuhan khusus}

Aktifitas ini bertujuan untuk memberikan pengetahuan tentang langkah-langkah identifikasi dan assesmen siswa berkebutuhan khusus. Tujuan dari kegiatan ini adalah agar subyek memahami bagaimana melakukan identifikasi subyek melalui asesmen yang benar, serta memberikan bekal pengetahuan kepada subyek ketika melakukan assesmen dilapangan. Asesmen ini menjadi dasar untuk mengetahui kondisi siswa berkebutuhan khusus sesungguhnya.

\section{d. Pelatihan Teknik-teknik intervensi} dengan pendekatan play therapy, teknik ABA dan teknik token ekonomi

Pada aktivitas ini, subyek diajarkan beberapa teknik dalam penanganan bagi siswa berkebutuhan khusus. Kegiatan ini bertujuan agar subyek memiliki pengetahuan tentang dasar-dasar dalam menyusun intervensi bagi siswa berkebutuhan khusus, sehingga mampu menyusun PPI yang sesuai dengan kondisi siswa. Dalam sesi ini subyek diminta melakukan role play dengan teman yang duduk disebelahnya untuk mempraktekkan 
beberapa teknik ABA yang diajarkan. Pada sesi ini, peneliti dibantu oleh terapis ahli yang berpengalaman dalam menangani siswa berkebutuhan khusus dengan jenis gangguan autis dan ADHD. Pada sesi ini subyek tampak mengikuti dengan sangat antusias sesi demi sesi, karena bagi mereka hal ini merupakan hal yang baru. Di akhir sesi subyek diminta untuk membuat rancangan terapi yang sederhana dengan menggunakan teknik yang telah diajarkan. Tujuannya agar subyek mampu membuat desain pembelajaran bagi siswa berkebutuhan khusus berdasarkan pelatihan yang telah diberikan.

\section{e. Kegiatan Asesmen lapangan}

Kegiatan ini dilakukan setelah subyek mendapatkan pengetahuan yang cukup tentang karakteristik siswa berkebutuhan khusus, teknik asesmen dan intervensi. Pada kegiatan ini subyek secara berkelompok melakukan identifikasi ke sekolah-sekolah inklusif untuk mencari siswa dengan gangguan sesuai materi presentasi mereka. Tujuan dari kegiatan ini adalah memberikan kesempatan kepada subyek untuk mengaplikasikan langsung teori-teori yang mereka dapat dari sesi sebelumnya. Disamping itu kegiatan ini bertujuan agar subyek mendapat pengalaman bagaimana proses melakukan identifikasi dan asesmen. Subyek juga diminta untuk membuat laporan hasil asesmen secara detil dan mempresentasikannya di depan kelas. Kegiatan ini juga bertujuan agar mereka saling berbagi pengalaman kepada kelompok lain maupun mendapat pengetahuan baru dari presentasi kelompok lain yang mendapat tema yang berbeda.

f. Pelatihan penyusunan Program Pengajaran Individual bagi siswa berkebutuhan khusus

Kegiatan ini dilakukan setelah proses assesmen dan presentasi hasil assesmen selesai. Terlebih dahulu subyek diberikan materi tentang teknik penyusunan program pengajaran individual sebanyak dua sesi, setelah itu subyek diminta untuk menyusun program PPI berdasarkan hasil assesmen yang sudah mereka lakukan. Tujuan kegiatan ini adalah untuk memberikan pengalaman langsung kepada subyek bagaimana menyusun program pengajaran individual. Kegiatan ini dilakukan secara individual dengan tujuan agar setiap orang membuat program secara mandiri, sekaligus untuk melakukan check-recheck terhadap pemahaman mereka terhadap materi. Subyek yang faham akan 
menunjukkan program yang detil dan dengan prosedur yang sesuai pengarahan yang telah diberikan, sebaliknya subyek yang tidak memahami materi akan tampak kurang sistematis dan kurang memaknai prosedur yang sudah dijelaskan.

\section{g. Deskripsi pemahaman subyek terhadap} program pembelajaran individual

Untuk mengetahui tingkat pemahaman subyek terhadap penyusunan program pengajaran individual, maka peneliti melakukan FGD kepada subyek. Proses ini dilakukan dengan meminta subyek untuk mempresentasikan hasil PPI nya didepan kelompok. Dilanjutkan dengan sesi Tanya jawab peneliti dengan subyek maupun diskusi subyek dengan anggota kelompoknya yang saling mengajukan pertanyaan. Dalam proses FGD ini peneliti memberikan penilaian kepada subyek. Adapun indikator penilaian adalah sebagai berikut:

1. Pemahaman subyek terhadap karakteristik gangguan secara umum (data didapat dari tugas assesmen kelompok)

2. Pemahaman subyek terhadap gangguan spesifik yang akan di intervensi.

3. Pemahaman subyek terhadap alasan subyek memilih intervensi jenis tersebut dan kaitannya dengan gangguan yang akan di intervensi

4. Kejelasan prosedur dan tahapan intervensi.

\section{h. Deskripsi hasil FGD program pembelajaran individual}

Untuk mengetahui gambaran pemahaman subyek tentang keempat aspek dalam penyusunan program pembelajaran individual peneliti mengkategorikan hasil FGD ke dalam empat kategori yaitu Sangat baik (SB), Baik (B), Sedang (S), Rendah (R). Berikut gambarannya dalam tabel 1

Tabel 2: Nilai FGD kelas A

\begin{tabular}{|c|c|c|c|}
\hline $\begin{array}{c}\text { Interval } \\
\text { Nilai }\end{array}$ & Kategori & $\begin{array}{c}\text { Jumlah } \\
\text { subyek }\end{array}$ & $\%$ \\
\hline $90-100$ & Sangat Baik & 12 & 25,5 \\
\hline $80-89$ & Baik & 15 & 31,9 \\
\hline $70-79$ & Sedang & 14 & 29,7 \\
\hline $60-69$ & Kurang & 6 & 12,7 \\
\hline \multicolumn{2}{|c|}{ Total } & 47 & 100 \\
\hline
\end{tabular}

Dari tabel tersebut diketahui bahwa subyek dalam penelitian ini sebagian besar memiliki pemahaman yang baik yaitu sebanyak 15 orang $(31,9 \%)$, diikuti dengan subyek yang memiliki pemaaman yang sedang sebanyak 14 orang $(29,7 \%)$, dan yang memiliki pemahaman yang sangat baik lebih banyak dibandingkan yang kurang yaitu sebanyak 12 orang $(25,5 \%)$. Hal ini berarti bahwa subyek lebih banyak 
memahami materi dibandingkan subyek yang tidak memahami materi.

Tabel 3: Deskripsi Nilai FGD kelas B

\begin{tabular}{|c|c|c|c|}
\hline $\begin{array}{c}\text { Interval } \\
\text { Nilai }\end{array}$ & Kategori & $\begin{array}{l}\text { Jumlah } \\
\text { subyek }\end{array}$ & $\%$ \\
\hline $90-100$ & Sangat Baik & 8 & 20,5 \\
\hline $80-89$ & Baik & 13 & 33,3 \\
\hline $70-79$ & Sedang & 10 & 25,6 \\
\hline $60-69$ & Kurang & 8 & 20,5 \\
\hline \multicolumn{2}{|c|}{ Total } & 39 & 100 \\
\hline
\end{tabular}

Dari tabel tersebut diketahui bahwa subyek yang memiliki kategori baik lebih banyak yaitu sebanyak 13 orang (33,3\%), diikuti dengan subyek yang memiliki pemahaman yang berada pada kategori sedang sebanyak 10 orang $(25,6 \%)$, sementara yang berada pada kategori sangat baik dan kurang berimbang yaitu samasama 8 orang $(20,5 \%)$.

Tabel 4. Perbandingan Tingkat Pemahaman Kelas A dan Kelas B terhadap Materi Pelatihan

\begin{tabular}{llllll}
\hline \multirow{2}{*}{$\begin{array}{c}\text { Interval } \\
\text { Nilai }\end{array}$} & \multicolumn{1}{c}{ Kategori } & \multicolumn{2}{c}{ Kelas A } & \multicolumn{2}{c}{ Kelas B } \\
\cline { 2 - 6 } & & $\begin{array}{c}\text { Jumlah } \\
\text { subyek }\end{array}$ & $\%$ & $\begin{array}{c}\text { Jumlah } \\
\text { subyek }\end{array}$ & $\%$ \\
\hline $90-100$ & Sangat Baik & 12 & 25,5 & 8 & 20,5 \\
\hline $80-89$ & Baik & 15 & 31,9 & 13 & 33,3 \\
\hline $70-79$ & Sedang & 14 & 29,7 & 10 & 25,6 \\
\hline $60-69$ & Kurang & 6 & 12,7 & 8 & 20,5 \\
\hline Total & & 47 & 100 & 39 & 100 \\
\hline
\end{tabular}

Meskipun jumlah subyek yang tidak berimbang, namun dapat dilihat bahwa subyek dari kelas A memiliki tingkat pemahaman yang lebih baik dari kelas $\mathrm{B}$ dalam hal menyusun program pembelajaran individual. Hal ini dapat dilihat dari jumlah subyek pada kategori sangat baik, baik dan sedang lebih banyak dibanding subyek dari kelas B. Begitupun dengan jumlah subyek yang berada pada kategori kurang, di kelas A lebih sedikit dibanding subyek di kelas B.

Selain data hasil FGD, peneliti pun memberikan angket evaluasi kepada setiap individu untuk memastikan seberapa mereka memahami materi-materi pelatihan yang diberikan selama 4 bulan. Angket tersebut berisi beberapa pertanyaan tentang pelatihan yang telah diberikan.

Pada pertanyaan pertama tentang seberapa penting pelatihan ini dilakukan sebagian besar subyek menjawab sangat penting terutama untuk membantu pendidikan inklusif.

Kemudian untuk pertanyaan tentang manfaat pelatihan, hampir sebagian besar memberikan jawaban mereka dapat memahami teknik identifikasi, assesmen dan menyusun 
PPI untuk siswa berkebutuhan khusus. Mereka pun sebagian besar memahami manfaat PPI terutama untuk menentukan program yang sesuai dengan gangguan yang dialami siswa. Merekapun sebagian besar menyatakan memahami tahapan dalam menyusun PPI. Namun kendala yang mereka hadapi dalam mengikuti pelatihan ini adalah sulitnya mencari subyek untuk proses asesmen, jauhnya lokasi subyek, waktu yang bersamaan dengan mata kuliah lain sehingga mereka merasa kurang waktu dalam melakukan asesmen, perizinan yang sulit, serta sulitnya referensi untuk gangguan yang baru seperti korban bencana dan siswa dari daerah tertinggal, termiskin, dan terbelakang (3 T).

Evaluasi mereka untuk pelatihan ini adalah mereka ingin diberikan waktu yang lebih panjang, dan diberi kesempatan untuk dapat menerapkan program pembelajaran individual yang telah mereka buat.

\section{PEMBAHASAN}

Pelatihan tentang penyusunan program pengajaran individual ini bertujuan untuk melatih mahasiswa agar mampu melakukan asesmen dan intervensi pada individu berkebutuhan khusus. Dari hasil penelitian diketahui bahwa subyek kelas sebagian besar memiliki pemahaman yang baik yaitu sebanyak
15 orang $(31,9 \%)$, diikuti dengan subyek yang memiliki pemahaman yang sedang sebanyak 14 orang $(29,7 \%)$, dan yang memiliki pemahaman yang sangat baik lebih banyak dibanding yang kurang yaitu sebanyak 12 orang $(25,5 \%)$. Hal ini berarti bahwa subyek lebih banyak memahami materi dibandingkan subyek yang tidak memahami materi, begitupun dengan subyek dari kelas B sebagaian besar memiliki kategori baik lebih banyak yaitu sebanyak 13 orang $(33,3 \%)$, diikuti dengan subyek yang memiliki pemahaman yang berada pada kategori sedang sebanyak 10 orang $(25,6 \%)$, sementara yang berada pada kategori sangat baik dan kurang berimbang yaitu sama-sama 8 orang $(20,5 \%)$. Hal ini membuktikan bahwa pelatihan penyusunan program pembelajaran individual yang telah dilakukan efektif untuk meingkatkan kemampuan subyek dalam melakukan asesmen maupun dalam menyusun intervensi yang sesuai dengan karakteristik kekhususan siswa berkebutuhan khusus.

Siswa berkebutuhan khusus merupakan siswa yang memerlukan pendidikan khusus dan pelayanan pendidikan yang khusus pula (Hallahan dan Kauffman; 2007) dan memerlukan pelayanan dan materi belajar yang berbeda dari anak normal agar mereka dapat belajar secara efektif (Gearheart, 
DOI: 10.21070/psikologia.v1i1.465

dalam Mangunsong, 2009). Namun kenyataan yang ada, terutam di Indonesia pelayanan pendidikan untuk mereka belum memadai. Siswa berkebutuhan khusus baru dapat mengenyam pendidikan bersama namun belum mendapat pelayanan pendidikan yang sesuai dengan kebutuhan mereka, hal ini menyebabkan kurang optimalnya pertumbuhan psikologis siswa berkebutuhan khusus selama mengikuti pembelajaran bahkan tidak jarang mereka menjadi barang asing yang kemudian mendapat perlakuan yang tidak baik dari teman-temannya di kelas.

Hal semacam ini tentu tidak akan terjadi apabila sekolah dan lingkungan siswa berkebutuhan khusus memiliki kesiapan, terutama kesiapan dalam menyusun program pembelajaran bagi siswa berkebutuhan khusus. Siswa berkebutuhan khusus ini memerlukan desain pembalajaran yang berbeda dari siswa regular. Mereka membutuhkan pendampingan dan arahan yang terus-menerus sampai target perilaku yang diharapkan mereka kuasai. Untuk itu pentingnya menyusunan program pembelajaran individual menjadi hal yang tidak dapat ditawar.

Mahasiswa sebagai bagian dari civitas akademika dapat dikerahkan untuk membantu memberikan pendampingan pada guru-guru inklusi terutama dalam memberikan pendampingan penyusunan program pembelajaran individual dengan supervisi dosen tentunya.

Penelitian ini merupakan penelitian yang mencoba membuktikan bahwa mahasiswa dapat diandalkan untuk melakukan observasi dan asesmen awal, kemudian diajarkan untuk menyusun program pembelajaran individual. Tujuan pelatihan ini adalah untuk melatih subyek mampu melakukan assesmen dan intervensi agar ia dapat melakukan kegiatan ini pada saat magang ataupun setelah mereka lulus.

Dari hasil penelitian diketahui bahwa subyek memiliki kemampuan yang baik dalam melakukan asesmen terhadap siswa ABK, mereka mampu mengidentifikasi karakteristik dengan cermat meskipun harus dengan beberapa kali evaluasi. Namun hal ini menjadi penting karena hasil asesmen merupakan bagian penting dalam menyusun program pembelajaran individual.

Berdasarkan hasil penelitian diketahui bahwa subyek sebagian besar memahami teknik menyusun program pembelajaran individual, mereka pun mampu menyusun intervensi dengan berbagai pendekatan, seperti menggunakan play therapy, teknik ABA dan teknik token ekonomi dan adapula yang menggunakan sosio drama maupun dengan 
menggunakan teknik cognitive behavior therapy (CBT).

Meskipun idealnya dalam pembuatan PPI, ada tiga tahapan penting yang harus selalu dilalui, yaitu perencanaan (planning), pelaksanaan (implementing), dan evaluasi (evaluating). Ketiga tahap tersebut terdiri atas tujuh komponen aktivitas yang perlu dilakukan, yaitu asesmen, kolaborasi, penulisan, pengenalan, pemantauan (monitoring), peninjauan (reviewing), dan pelaporan (Ministry of Education Province of British Columbia, 2009), namun dalam pelatihan ini mereka baru dalam tahap melakukan perencanaan (planning) belum pada tahap penerapan dan evaluasi. Hal ini disebabkan karena keterbatasan waktu pelatihan.

Meskipun waktu yang tersedia hampir 4 bulan lebih dengan pertemuan seminggu 2 kali, namun dengan padatnya materi pelatihan ditambah peserta masih mengikuti perkuliahan lain bahkan beberapa masih magang di sekolah, membuat pelaksanaan pelatihan ini menjadi kurang optimal. Mereka belum dapat melakukan tahap implementasi dari program pembelajaran individual yang dibuat dan belum maupuan evaluasi untuk melihat kekurangan dari program yang dibuat.
Meskipun demikian, dari sisi perencanaan mereka telah mampu membuat program pembelajaran individual yang baik, sistematis dan dengan berbagai variasi tahap. Mereka telah mampu membuat desain pembelajaran dengan pendekatan pembelajaran yang menyenangkan seperti play therapy. Hanya saja mereka tampak kurang mampu memahami dinamika psikologis atau keterkaitan antara intervensi yang digunakan dengan perubahan perilaku yang ditargetkan. Perlu waktu dan pendalaman yang intensif untuk membuat mereka menyadari pentingnya kegiatan didasarkan pada kajian-kajian penelitian terdahulu

\section{SIMPULAN}

Subyek memiliki pemahaman yang baik dalam menangkap dan mempraktekkan materi pelatihan, dimana dari kedua kelas, subyek yang memiliki pemahaman yang baik lebih banyak dari pada subyek yang kurang memahami. Hal ini menunjukkan bahwa pelatihan ini efektif dalam meningkatkan pengetahuan subyek tentang penyusunan program pembelajaran individual.

Pelatihan ini baru sebatas pada tahap perencanaan dari tiga aktifitas yang harus dilalui dalam penyusunan program pengajaran 
individual yaitu planning, impelementing dan evaluating.

Beberapa manfaat yang dirasakan subyek dalam mengikuti pelatihan ini adalah mereka menjadi memiliki empati terhadap siswa berkebutuhan khusus, mampu melakukan asesmen dan menyusun program pembelajaran bagi siswa berkebutuhan khusus.

Terbatasnya waktu untuk menerapkan program intervensi yang telah disusun, sehingga peneliti belum dapat mengevaluasi program yang diterapkan pada siswa berkebutuhan khusus.

Perlunya program pendampingan yang berkelanjutan dan waktu yang lebih banyak dalam mengajarkan subyek menyusun program pembelajaran bagi siswa berkebutuhan khusus serta evaluasi program agar subyek benar-benar memahami kelemahan dan kelebihan dari program yang telah dibuatnya.

\section{DAFTAR PUSTAKA}

Biederman, J., Faraone M. D., \& Monuteaux, M. C. (2002). Differential effect of environmental adversity gender: Rutter's index of adversity in a group of boys and girls with and without ADHD. Journal Psychiatry, 158,1556-1562.

Cristensen, L. B. (1988). Experimental Methodology. London: Allyn and Bacon, Inc.
Creswell, J.W. (2008). Educational Research: Planning, Conducting, and Evaluating Quantitative and Qualitative Research. Third edition. United States of America: Pearson education, Inc.

Direktorat Pembinaan Sekolah Luar Biasa, Direktorat Jenderal Manajemen Pendidikan Dasar dan Menengah, Departemen Pendidikan Nasional. (2007). Model Pembelajaran dan Pendidikan Penyelenggaraan Pendidikan Inklusif: Pedoman Umum Penyelenggaraan Pendidikan Inklusif.

Dinas Pendidikan Pemerintah Kota Surabaya. (2014). Pelaksanaan dan permasalah pendidikan ABK di Surabaya. Makalah Seminar \& Workshop pembentukan jaringan kerjasama dan penanganan ABK. UNESA:Surabaya.

Freind, M. (2005). Special Education Contemporary perspective for School Professional. United State of America: Pearson Education, Inc:

Fletcher, J. M. (1994). Cognitive profile of reading disability: Comparisons of discrepancy and low achievement definitions. Journal of Educational Psychology, 84(1), 6-23.

Freidman, Youngwirth, \& Goldstein. (2007). The relation between 3-year-old children's skills and their hyperactivity, inattention, and aggression. Journal of Educational Psychology, 99(3), 671681.

Hallahan, D.P., Kauffman, J.M., \& Pullen, P. C. (2009). Exceptional Learners. An Introduction to Special Education. United States of America: Pearson education, Inc. 
Mangunsong, F. (2009).Psikologi dan Pendidikan anak Berkebutuhan Khusus. Jilid 1. LPSP3UI:Jakarta

Pendidikan Anak Berkebutuhan khusus. Jilid 2.LPSP3UI: Jakarta.

Ministry of Education Province of British Columbia, (2009).The Individualized Education Program Individual (IEP).www.directinservice.org/cadre/ parent/artifact/VFN4\%20IEP\%2001.09.pdf).

Nimatuzahroh, Nurhamidah, Y. (2016). Pengembangan Model Kelas Inklusi Berbasis Komunitas Tingkat Sekolah Dasar Kota Malang. Hibah Bersaing Tahun ke II. DIKTI.

Rief, S. F. (1993). How to Reach and Teach ADD/ADHD ChiLDren. The Center for Applied Research in Education. New York. America.

Stubs, S. (2002). Inclusive Education where there are few resources. Oslo: The Atlas Alliance.

Seniati, L, Yulianto, A, \& Setiadi, B.N. (2007). Psikologi Eksperimen. Jakarta: PT. Macanan Jaya Cemerlang.

Thomas, G., \& Hanlon, C. (2007). Inclusive Education: Deconstructing special Education \& Contructing Inclusion. Second Edition. Mc.Graw Hill: Open University Press.

Visser, J., Daniels, H \& Cole, T. (2001). International Perspective on Inclusive Education, Volume 1, Emotional \& Behavioural Difficulties in Mainstream School. Elsevier Science Ltd:UK 